\title{
HUBUNGAN POLA ASUH ORANG TUA DENGAN PERILAKU BULLYING PADA SISWA SMA AL-AZHAR 3 BANDAR LAMPUNG TAHUN 2019
}

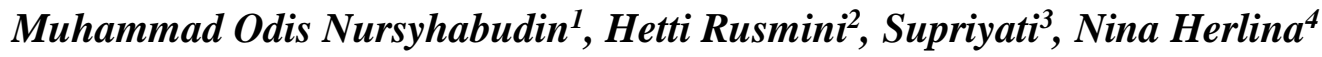 \\ Email: muhammad.odis@yahoo.com \\ ${ }^{1}$ Program Studi Kedokteran Fakultas Kedokteran Universitas Malahayati \\ ${ }^{2}$ Departemen Farmakologi Fakultas Kedokteran Universitas Malahayati \\ ${ }^{3}$ Departemen Psikologi Fakultas Kedokteran Universitas Malahayati \\ ${ }^{4}$ Departemen Perinatologi Rumah Sakit Urip Sumoharjo Bandar Lampung
}

\begin{abstract}
Bullying cases that often occur in the world of education in Indonesia are increasingly alarming. The impact of bullying can cause a child who is a victim to be hampered in self-actualization. There are several factors that influence bullying behavior, one of which is parenting style or parenting. The purpose of this research was to determine the correlation between parenting style with bullying behavior in high school students.This type of research is a descriptive observational analytic method using the Cros Sectional design. The sample in this study was that all students of class XII Natural Sciences / Social Sciences at Al-Azhar 3 Bandar Lampung High School were 176 students. Data obtained through filling the bullying behavior scale consists of 29 items and the parenting scale consists of 30 items. Data analysis technique to test the hypothesis is Anova One Way. The results showed that most of the respondents with democratic parenting were 113 respondents $(64.2 \%)$, the majority of respondents with low bullying behavior were 119 respondents (67.6\%) and there was a relationship between parenting patterns with bullying behavior in SMA AL-AZHAR 3 students in Bandar Lampung ( $p$ value 0,000). The research showed a correlation between parenting style with behavior bullying in senior high school students of Al-Azhar 3 Bandar Lampung 2019.
\end{abstract}

Keywords : Bullying Behavior, Parenting Style

\begin{abstract}
Abstrak
Kasus bullying yang kerap terjadi dalam dunia pendidikan di Indonesia kian memprihatinkan. Dampak bullying dapat menyebabkan seorang anak yang menjadi korban akan terhambat dalam aktualisasi diri. Ada beberapa faktor yang mempengaruhi perilaku bullying salah satunya yaitu parenting style atau pola asuh. Penelitian ini ditujukan mengetahui hubungan pola asuh orang tua dengan perilaku bullying pada siswa SMA AL-AZHAR 3 Bandar Lampung. Jenis penelitian yang digunakan adalah penelitian deskiptif metode analitik observasional menggunakan desain Cros Sectional. Sampel dalam penelitian ini yaitu seluruh siswa kelas XII IPA/IPS SMA Al-Azhar 3 Bandar Lampung sebanyak 176 siswa. Data diperoleh melalui mengisi skala perilaku bullying terdiri dari 29 aitem dan skala pola asuh orangtua terdiri dari 30 aitem. Teknik analisis data untuk menguji hipotesis yaitu Anova One Way. Dari hasil penelitian menunjukkan bahwa sebagian besar responden dengan pola asuh demokratif yaitu sebanyak 113 responden (64,2\%), sebagian besar responden dengan perilaku bullying rendah yaitu sebanyak 119 responden $(67.6 \%)$ dan ada hubungan antara pola asuh orang tua dengan perilaku bullying pada siswa SMA AL-AZHAR 3 Bandar Lampung (p value 0,000). Terdapat hubungan antara pola asuh orangtua dengan perilaku bullying pada siswa SMA Al-Azhar 3 Bandar Lampung Tahun 2019.
\end{abstract}

Kata Kunci : Perilaku Bullying, Pola Asuh Orangtua.

\section{PENDAHULUAN}

Undang-Undang Dasar Negara

Republik Indonesia Tahun 1945 Pasal

28B ayat (2) menyatakan bahwa setiap anak berhak atas kelangsungan hidup, tumbuh dan berkembang serta berhak atas perlindungan dari kekerasan dan diskriminasi. Selain itu, menurut 
Undang-Undang Perlindungan Anak No.

23 Tahun 2002 menjelaskan bahwa harapan anak Indonesia akan tumbuh dan berkembang menjadi anak yang sehat, ceria, dan berakhlah mulia. Bagian keempat dalam Undang-Undang Perlindungan Anak No. 23 Tahun 2002, menjelaskan tentang kewajiban dan tanggung jawab keluarga dan orang tua.

Saat ini, bullying merupakan istilah yang sudah tidak asing di telinga masyarakat Indonesia. Bullying adalah tindakan penggunaan kekuasaan untuk menyakiti seseorang atau sekelompok orang baik secara verbal, fisik, maupun psikologis sehingga korban merasa tertekan, trauma, dan tak berdaya (Sejiwa, 2008). Pelaku bullying sering disebut dengan istilah bully. Seorang bully tidak mengenal gender maupun usia. Bahkan, bullying sudah terjadi di sekolah dan dilakukan oleh para remaja. Bullying (dalam Bahasa Indonesia dikenal sebagai "penindasan/risak") merupakan segala bentuk penindasanatau kekerasan yang dilakukan dengan sengaja oleh satu orang atau sekelompok orang yang lebih kuat atau berkuasa terhadap orang lain, dengan tujuan untuk menyakiti dan di lakukan terus menerus.
Terdapat banyak definisi mengenai bullying, terutama yang terjadi dalam konteks lain seperti dirumah, tempat kerja, masyarakat, komunitas virtual. Namun dalam hal ini dibatasi dalam konteks school bullying atau bullying di sekolah. Riauskina, Djuwita, dan Soesetio (2005) mendefinisikan school bullying sebagai perilaku agresif yang dilakukan berulang-ulang oleh seorang atau sekelompok siswa yang memiliki kekuasaan, terhadap siswa/siswi lain yang lebih lemah, dengan tujuan menyakiti orang tersebut. Kasus bullying yang kerap terjadi dalam dunia pendidikan di Indonesia kian memprihatinkan. Hasil kajian Konsorsium Nasional Pengembangan Sekolah Karakter tahun 2014 menyebutkan, hampir setiap sekolah di Indonesia ada kasus bullying, meski hanya bullying verbal dan psikologis/mental.

Selain itu, menurut penelitian yang dilakukan oleh Yayasan Semai Jiwa Amini (SEJIWA) tahun 2008 yang bekerja sama dengan Plan Indonesia dan Universitas Indonesia tentang kekerasan bullying di kota besar di Indonesia yaitu di Yogyakarta, Jakarta, dan Surabaya mencatat terjadinya tingkat kekerasan sebesar $67,9 \%$ di tingkat Sekolah 
Menengah Atas (SMA) dan 66,1\% di tingkat Sekolah Menegah Pertama (SMP). Kekerasan yang dilakukan sesama siswa tercatat sebesar $41,2 \%$ untuk tingkat SMP dan 43,7\% untuk tingkat SMA dengan kategori tertinggi berupa pengucilan. Peringkat kedua ditempati kekerasan verbal (mengejek) dan terakhir kekerasan fisik (memukul). Berdasarkan hasil penelitian tersebut dapat disimpulkan bullying terjadi hampir diseluruh sekolah, baik yang ringan hingga berat.

Dampak bullying dapat menyebabkan seorang anak yang menjadi korban akan terhambat dalam aktualisasi diri. Bullying tidak memberi rasa aman dan nyaman, sehingga membuat korban takut, terintimidasi rendah diri, serta merasa tidak berharga, penyesuaian sosial yang buruk di mana korban merasa takut ke sekolah bahkan tidak mau sekolah, menarik diri dalam pergaulan, prestasi akademik menurun karena mengalami kesulitan untuk berkonsentrasi dalam belajar, bahkan keinginan untuk bunuh diri dari pada harus menghadapi tekanan-tekanan berupa hinaan dan hukuman (Yayasan Sejiwa, 2008).

Menurut Dake, (2003) ada beberapa faktor yang mempengaruhi perilaku bullying yaitu sosial ekonomi keluarga, tingkat pendidikan orang tua, lingkungan sekolah kurang baik, keharmonisan keluarga, dan parenting style atau pola asuh. Pola asuh orang tua dapat diartikan sebagai seluruh cara perlakuan orang tua yang diterapkan pada anaknya. Pola asuh juga biasa diartikan sebagai interaksi yang dilakukan oleh orang tua dengan anak dimana dalam interaksinya tersebut keluarga memberikan pengasuhan berupa penilaian, pendidikan, pengetahuan, bimbingan, kedisiplinan, kemandirian, dan perlindungan berkaitan dengan kepentingan hidupnya (Shochib, 2010). Dalam Kamus Bahasa Indonesia (2003) pola asuh atau pengasuhan merupakan cara perbuatan untuk menjaga, merawat, mendidik, membimbing, anak-anaknya agar berkembang sesuai tahapannya. Pengasuhan orang tua diharapkan dalam memberikan kedisiplinan terhadap anak, memberikan tanggapan yang sebenarnya agar anak merasa orang tua selalu memberikan perhatian positif terhadapnya.

Pola pengasuhan (parenting style) sangat bergantung pada nilai-nilai yang dimiliki keluarga. Peran pengasuhan dapat dipelajari melalui 
proses sosialisasi selama tahap perkembangan anak-anak yang dijalankan melalui interaksi antara keluarga. Anak yang mempunyai interaksi yang baik dengan keluarga cenderung selalu mempunyai kesempatan untuk mendapatkan perhatian, kasih sayang, dan anak akan lebih terpantau oleh keluarganya (Hawari, 2007). Hasil penelitian putri (2014) menjelaskan bahwa ketidakharmonisan keluarga berpengaruh terhadap perilaku bullying yang dilakukan oleh anak karena anak merasa kurang perhatian dan meluapkan emosinya dengan berbuat semaunya termasuk berperilaku kasar pada temannya.

Baumrind (2011) menjelaskan pola asuh orang tua dibagi menjadi tiga tipe, yaitu otoriter, demokratif, dan permisif. Masing-masing pola asuh tersebut memiliki karakteristik yang berbeda dan dapat memberikan dampak yang berbeda juga terhadap pola perkembangan anak. Dijelaskan pada pola asuh otoriter, ditandai dengan adanya aturan-aturan yang kaku dari orang tua, cenderung untuk menentukan peraturan tanpa berdikusi dengan anakanak mereka terlebih dahulu. Pada pola asuh demokratis, orang tua lebih mendorong kemandirian pada batasan tertentu, hangat dan penuh kasih sayang sehingga anak mampu berkompeten secara sosial, maupun bergantung pada diri sendiri bertanggung jawab secara sosial. Selanjutnya pada pola asuh permisif yang sedikit terlibat dengan anak dan tidak menyadari apa yang dilakukan anak.

Setiap pola asuh memberikan dampak yang berbeda-beda. Pola asuh otoriter akan sangat berpengaruh pada perkembangan kepribadian anak seperti anak akan berkembang menjadi penakut, kurang percaya diri, dan merasa tidak berharga. Pola asuh demokratis mempunyai kelebihan yaitu orang tua memberikan kebebasan berpendapat kepada anaknya sehingga akan terjadi keseimbangan antara orang tua dan anak, sedangkan pola asuh permisif akan menumbuhkan sikap ketergantungan dan sulit menyesuaikan diri dengan lingkungannya (Depkes, 2012).

\section{METODE PENELITIAN}

Jenis penelitian yang digunakan adalah penelitian deskiptif metode analitik observasional menggunakan desain Cros Sectional. Sampel dalam penelitian ini yaitu seluruh siswa kelas XII IPA/IPS SMA Al-Azhar 3 Bandar Lampung. Data diperoleh melalui 
mengisi skala perilaku bullying terdiri dari 29 aitem dan skala pola asuh orangtua terdiri dari 30 aitem. Penelitian ini dilakukan di SMA Al-Azhar 3 Bandar Lampung, sedangkan waktu penelitiannya adalah November 2019.

Sampel dalam penelitian ini adaah seluruh siswa kelas XI IPA/IPS SMA Al-AZHAR 3 Bandar Lampung sebanyak 176 siswa.

Kriteria inklusi pada penelitiam ini adalah siswa dan Siswi SMA ALAzhar yang duduk dikelas XI, siswa yang masih memiliki orang tua yang masih hidup dan tinggal satu rumah dan bersedia menjadi responden. Kriteria ekslusi pada penelitian ini adalah responden tidak hadir atau mengundurkan diri dari proses penelitian dan responden tidak mengisi kuesioner dengan lengkap.

\section{HASIL PENELITIAN DAN PEMBAHASAN}

Tabel 1. Karakteristik Responden

\begin{tabular}{llcc}
\hline Karakteristik & Responden & Jumlah & $\begin{array}{c}\text { Persentase } \\
(\mathbf{\%})\end{array}$ \\
\hline 1. Jenis & Laki-laki & 79 & 44,9 \\
Kelamin & Perempuan & 97 & 55,1 \\
\hline & Total & $\mathbf{1 7 6}$ & $\mathbf{1 0 0 , 0}$ \\
\hline 2. Usia & 15 Tahun & 17 & 9,7 \\
& 16 Tahun & 127 & 72,2 \\
& 17 Tahun & 30 & 17,0 \\
& 18 Tahun & 2 & 1,1 \\
\hline Total & $\mathbf{1 7 6}$ & $\mathbf{1 0 0 , 0}$ \\
\hline
\end{tabular}

Berdasarkan tabel 1 di atas diketahui bahwa sebagian besar responden berjenis kelamin perempuan, yaitu sebanyak 97 responden (55.1\%), sedangkan yang berjenis kelamin lakilaki sebanyak 79 responden $(44,9 \%)$ dan sebagian besar responden berusia 16 tahun yaitu 127 responden $(72,2 \%)$, dan yang paling sedikit adalah responden dengan usia 18 tahun yaitu 2 responden $(1,1 \%)$.

Tabel 2. Bullying

\begin{tabular}{cccc}
\hline No & Perilaku Bullying & Jumlah & Persentase \\
\hline 1 & Tinggi & 7 & 4.0 \\
2 & Sedang & 50 & 28.4 \\
3 & Rendah & 119 & 67.6 \\
\hline & Total & $\mathbf{1 7 6}$ & $\mathbf{1 0 0 . 0}$ \\
\hline
\end{tabular}

Berdasarkan tabel 2 di atas diketahui bahwa sebagian besar responden dengan perilaku bullying rendah yaitu sebanyak 119 responden $(67.6 \%)$.

Tabel 3. Pola Asuh Orang Tua

\begin{tabular}{lccc}
\hline No & Pola Asuh & Jumlah & Persentase \\
\hline 1 & Otoriter & 9 & 5.1 \\
2 & Demokratif & 113 & 64.2 \\
3 & Permisif & 54 & 30.7 \\
\hline & Total & $\mathbf{1 7 6}$ & $\mathbf{1 0 0 . 0}$ \\
\hline
\end{tabular}

Berdasarkan table 3 di atas diketahui bahwa sebagian besar responden dengan pola asuh demokratif yaitu sebanyak 113 responden $(64,2 \%)$.

Tabel 4. Hubungan Antara Pola Asuh Orang Tua dengan Perilaku Bullying

\begin{tabular}{|c|c|c|c|c|c|}
\hline \multirow{3}{*}{$\begin{array}{l}\text { Pola Asuh } \\
\text { Orang Tua }\end{array}$} & \multicolumn{4}{|c|}{ Perilaku Bullying } & \multirow{3}{*}{$\begin{array}{c}P \\
\text { value }\end{array}$} \\
\hline & Tinggi & Sedang & Rendah & Total & \\
\hline & $n \%$ & $\%$ & $n \quad \%$ & $\%$ & \\
\hline Otoriter & 333.3 & 222.2 & $4 \quad 44.4$ & $9 \quad 100.0$ & 0,000 \\
\hline Demokratif & $4 \quad 3.5$ & $40 \quad 35.4$ & $69 \quad 61.1$ & $113 \quad 100.0$ & \\
\hline Permisif & $0 \quad 0.0$ & $8 \quad 14.8$ & $46 \quad 85.2$ & $54 \quad 100.0$ & \\
\hline Total & 74.0 & $50 \quad 28.4$ & $119 \quad 67.6$ & $176 \quad 100.0$ & \\
\hline
\end{tabular}


Berdasarkan hasil analisa, diketahui bahwa dari 9 responden dengan pola asuh otoriter, sebanyak 3 responden $(33,3 \%)$ berperilaku bullying tinggi. Dari 113 responden dengan pola asuh demokratif, sebanyak 69 responden $(61,1 \%)$ berperilaku bullying tinggi, sedangkan 54 responden dengan pola asuh permisif, sebanyak 46 responden $(85,2 \%)$ berperilaku bullying tinggi. Hasil uji statistik diperoleh nilai $p$ value 0,000 maka dapat disimpulkan bahwa ada hubungan antara pola asuh orang tua dengan perilaku bullying pada siswa SMA AL-AZHAR 3 Bandar Lampung.

Hasil penelitian menunjukkan bahwa sebagian besar responden dengan perilaku bullying rendah yaitu sebanyak 119 responden (67.6\%). Perilaku bullying sedang dengan kategori jenis perilaku bullying verbal pada penelitian ini dapat dilihat pada hasil kuesioner butir $3(42,3 \%)$ responden menyatakan bahwa kadang-kadang mengejek teman dengan sebut an gendut/cungkring/bencong/tonggs, butir nomer $4(40,2 \%)$ responden menyatakan bahwa sering memanggil dengan nama jelak dan butir nomer $10 \quad(38,1 \%)$ responden megatakan sering mengolokolok teman lain.
Hal ini sesuai dengan pendapat Rigby (2008) yang menjelaskan bahwa bullying kategori sedang (intermediate) terjadi saat seseorang mengalami bentuk pelecehan dan penghinaan yang secara sistematik dan meyakinkan selama periode waktu yang cukup lama (9-16 hari dalam satu bulan). Tindakannya dalam meliputi ejekan yang kejam, pengucilan yang berkelanjutan dan beberapa ancaman dan serangan fisik yang halus, contohnya mendorong, menjegal, menarik baju.

Perilaku bullying dalam kategori tinggi dalam penelitian ini sebanyak 7 responden (4,0\%). Hal ini menunjukakan bahwa perilaku bullying dalam kategori tinggi biasanya memiliki tindakan yang lebih kejam dengan intentitas waktu yang cukup panjang dan lama. Hal ini didukung dengan pendapat Rigby (2008) yang menjelaskan bullying kategori tinggi (severe) melibatkan intimidasi dan tekanan yang kejam dan intens terutama saat hal tersebut terjadi dalam jangka waktu yang panjang dan cukup lama dan dapat menimbulkan distress bagi korbannya. Bullying dalam kategori ini sering melibtkan serangan fisik yang cukup ekstrim seperti memukul, menendang, melukai dengan senjata, namun bisa juga melibatkan aksi non- 
fisik seperti persaingan total dari kelompok, fitnah yang kejam dan sarkasme yang berlebihan.

Penelitian ini juga menunjukan perbedaan dengan penelitian Pratiwi (2016) yang menunjukan bahwa perilaku bullying dalam kategori tinggi. Ada beberapa faktor yang dapat mempengaruhi perbedaan hasil tersebut, hal ini terkait dengan faktor lingkungan sekolah yaitu sekolah kurang memberikan perhatian terhadap kasus bullying yang terjadi di sekolah. Guru terkesan tidak peduli dan kurang tanggap terhadap permasalahan yang terjadi. Ditinjau dari karakteristik responden menunjukkan frekuensi usia responden kelas VIII SMP Muhammadiyah 2 Gamping Sleman Yogyakarta menunjukkan bahwa usia paling dominan adalah usia14 dan15 tahun, anak dengan usia 14 -15 tahun termasuk dalam usia remaja.

Hal ini sesuai dengan teori Daryo (2007) bahwa remaja merupakan masa transisi (peralihan) untuk menuju masa dewasa, remaja adalah mereka yang berumur 13 sampai 21 tahun, dimana remaja mengalami perubahan fisik, kematangan organ seksual, kognisi, kepribadian, bersosialisasi, mulai mencari identitas dirinya dengan berbagai cara dan pengalaman yang mereka pilih. Hal ini didukung oleh teori Sarwono (2016) yang menjelaskan usia remaja adalah 11-24 tahun dan belum menikah dengan pertimbangan dari segi fisik, psikis, psiko-sosial dan ekonomi serta kebudayaan. Kalangan pakar psikologi perkembangan membagi masa remaja menjadi remaja awal 13-16 tahun atau 17 tahun dan remaja akhir 16 tahun atau 17 tahun sampai 19 tahun.

Masa remaja awal dan akhir dibedakan individu telah mencapai masa transisi perkembangan yang lebih mendekatimasa dewasa. Usia remaja awal biasanya mengalami perubahan perkembangan sosio-emosional. Perubahan emosi biasanya dilihat dari perubahan tingkah lakunya.

Hal ini sesuai dengan teori Ali (2010) yang menjelaskan perubahan emosi remaja awal biasanya tampak jelas pada perubahan tingkah lakunya. Remaja awal biasanya memiliki emosi yang berkobar-kobar, energi yang besar, sedangkan pengendalian diri belum sempurna, sehingga sering mengalami perasaan yang tidak aman, tidak tenang, dan khawatir kesepian, sehingga dikatakan emosi remaja masih labil.

Hal ini juga didukung dengan teori Monks dan Knoers (2004) bahwa 
perubahan emosi remaja awal sangat berkaitan dengan perubahan sosial. Perubahan sosial yang terjadi, yaitu remaja akan lebih dekat dengan teman sebayanya dan memisahkan diri dari orang tua dengan maksud menemukan jati diri, remaja membentuk kelompok dan mengekspresikan segala potensi yang dimiliki. Pada masa remaja awal cenderung ingin mencoba hal-hal baru, baik hal positif maupun hal negatif, hal negatif salah satunya adalah kenakalan remaja.

Hasil penelitian menunjukkan bahwa sebagian besar responden dengan pola asuh demokratif yaitu sebanyak 113 responden $(64,2 \%)$. Penelitian ini sejalan dengan penelitian Yuniartiningtyas (2013) yang menemukan responden berpola asuh negatif dengan rincian pola asuh permisif sebanyak 66 responden (69\%) dan otoriter sebanyak 15 responden (17\%) di SMP Negeri 1 Gudo Jombang. Hal ini menunjukan bahwa orang tua yang membesarkan anak dengan pola asuh negatif akan cenderung tumbuh dan berkembang dengan kurang baik karena faktor keluarga memberikan kontribusi terhadap perkembangan perilaku anak.

Hal ini sesuai dengan pendapat Priyatna (2010) bahwa pola asuh dalam suatu keluarga mempunyai peranan penting dalam pembentukan perilaku. Keluarga yang menerapakan pola asuh permisif lebih cenderung memberikan kebebasan kepada anak akan membuat anak terbiasa berperilaku bebas sesuatu yang diinginkannya, tidak peduli perilaku itu sesuai dengan norma masyarakat atau tidak. Anak menjadi manja, akan memaksakan keinginannya.

Begitu pula dengan pola asuh otoriter, yang cenderung mengekang kebebasan anak. Anak pun terbiasa mendapatkan perlakuan kasar yang nantinya anak akan mempraktikan dalam pertemanannya bahkan anak akan menganggap hal tersebut sebagai hal yang wajar. Pola asuh orang tua paling sedikit pada penelitian ini adalah pola asuh dalam kategori positif yang terdiri dari pola asuh demokratis sebanyak 9 responden $(9,3 \%)$.

Hal ini sesuai dengan penelitian Yuniartiningtyas (2013) yang menemukan responden berpola asuh positif dengan rincian pola asuh demokratis sebanyak 12 responden (14\%). Hal ini menunukkan bahwa orang tua yang membesarkan anak dengan pola asuh positif akan cenderung tumbuh dan berkembang dengan baik. Hal ini didukung dengan pendapat 
Sanjaya (2011) bahwa pola asuh demokratis adalah pola asuh menyeimbangkan pemikiran, sikap dan tindakan antara anak dan orang tua. Orang tua dengan pola asuh demokratis lebih memberikan penjelasan-penjelasan mengapa sesuatu boleh atau tidak boleh dilakukan. Orang tua terbuka untuk berdiskusi dengan anak. Orang tua melihat anak sebagai individu yang patut didengar, dihargai, dan diberi kesempatan.

Hasil penelitian menunjukkan bahwa ada hubungan antara pola asuh orang tua dengan perilaku bullying pada siswa SMA AL-AZHAR 3 Bandar Lampung. Penelitian yang mendukung hasil penelitian ini seperti yang dilakukan Annisa (2012) tentang hubungan antara pola asuh ibu dengan perilaku bullyingremaja di SMK Cikini, dan hasil penelitian ini menunjukkan adanya hubungan antara pola asuh ibu dengan perilaku bullyingremaja di sekolah SMK Cikini, Pola asuh ibu yang otoriter memiliki keterlibatan dalam perilaku bullyingpada remaja dengan frekuensi 56 siswa (61,5\%) yang melakukan perilaku bullying.

Pola asuh otoriter adalah pola asuh yang terlalu keras sehingga anak menjadi akrab dengan suasana yang mengancam dan juga sikap orang tua yang memberikan contoh perilaku bullying yang disengaja maupun tidak sengaja dapat membuat anak terbiasa dengan perilaku bullying dalam lingkungannya (Astuti, 2008).

Penelitian lain yang dilakukan Nurhayati (2013) tentang tipe pola asuh orang tua yang berhubungandengan perilaku bullying di SMA Islam Sudirman Ambarawa Kabupaten Semarang menyatakan adanya hubungan antara pola asuh demokratis dengan perilaku bullying. Dengan perilaku bullying ringan sebanyak 51 siswa $(58,0 \%)$, perilaku bullying sedang 31 siswa $(35,2 \%)$ sedangkan perilaku bullyingberat 6 siswa $(6,8 \%)$.

Seperti yang diketahui perilaku bullying juga disebabkan oleh pola asuh demokratis dan permisif walaupun jumlahnya tidak banyak seperti pola asuh otoriter. Menurut Willis (2013) keluarga dan sekolah adalah dua sistem yang sangat penting di dalam kehidupan anak dan remaja. Keluarga berperan utama dalam mempengaruhi anak -anak dalam perkembangan dan sosialnya, diantaranya berkomunikasi, menyatakan perasaan, belajar nilai-nilai. Saat anak memasuki sekolah, sekolah tidak hanya mengembangkan ketrampilan kognitif, 
akan tetapi juga mempengaruhi emosional dan sosial. (Willis, 2013)

Saat di sekolah anak bergaul dengan teman sebayanya. Salah satu faktor yang mempengaruhi tingkah laku anak adalah bergaul dengan teman teman sebaya yang delinkuen. Manusia yang hidup berkelompok, tidak terkecuali dengan remaja. Mereka berinteraksi dengan sesama mereka pada tingkat umur yang sama. Kelompok ini mudah terpengaruh dengan tingkah laku teman sebaya terutama tingkah laku yang melanggar peraturan atau disiplin, sehingga mendapat pengakuan dari kelompok tersebut.

\section{PENUTUP}

Hasil penelitian menunjukkan bahwa sebagian besar responden dengan pola asuh demokratif yaitu sebanyak 113 responden $(64,2 \%)$. Hasil penelitian menunjukkan bahwa sebagian besar responden dengan perilaku bullying rendah yaitu sebanyak 119 responden (67.6\%). Hasil penelitian menunjukkan bahwa ada hubungan antara pola asuh orang tua dengan perilaku bullying pada siswa SMA AL-AZHAR 3 Bandar Lampung ( $p$ value 0,000 ).

\section{DAFTAR PUSTAKA}

Annisa., 2012 . Hubungan Antara Pola Asuh Ibu dengan Perilaku Bullying Remaja. Skripsi. Depok
: Fakultas Ilmu Keperawatan Universitas Indonesia

Astuti, P.R., 2008. Meredam Bullying. Jakarta: Grasindo.

Coloroso., 2007. Stop Bullying: Memutus Rantai Kekerasan Anak dari Prasekolah Hingga SMU. Jakarta: Ikrar Mandiriabadi.

Dake, J.A., Prince, J.H., Telljohann, S.K., 2003. The Nature and Extent of Bullying at School. Journal of school health. Vol. 73, No.5:173-180.

Depdikbud., 2003. Kamus Besar Bahasa Indonesia. Jakarta: Balai Pustaka

Desmita., 2012. Psikologi Perkembangan Peserta Didik. Bandung: Remaja Rodakarya.

Elvigro dan Paresma., 2014. Secangkir Kopi Bully. Jakarta:Gramedia.

Erine dan Villa., 2012. Hubungan Pola Asuh Orang Tua dengan Perilaku Merokok di Desa Cendono Kecamatan Dawe Kabupaten Kudus.

Kharie., 2014. Hubungan Pola Asuh Orang Tua Dengan Perilaku Merokok Pada Anak Laki-Laki Usia 15-17 Tahun Di Kelurahan Tanah Raja Kota Ternate.

Korua, S., 2015. Hubungan Pola Asuh Orang Tua Dengan Perilaku Bulliyng Pada Remaja SMK Negeri 1 Manado. E-journal Keperawatan, Volume 3, No. 2, Hal 1-7. 
Kustanti, Erin Ratna., 2015. Gambaran Bullying pada Pelajar di Kota Semarang. Jurnal Psikologi Undip Vol. 14 No. 1. Tersedia di https://ejournal.undip.

ac.id/index.php/psikologi/article/ view/9796, diakses tanggal 3 September 2019.

Lestari, Dwi Andriani., 2018. Pengaruh Pola Asuh Orang Tua Terhadap Perilaku Bullying Melalui Interaksi Teman Sebaya Pada Siswa Kelas V Sekolah Dasar Di Kota Malang. Tesis. Malang : Fakultas Pascasarjana Magister Pendidikan Guru Madrasah Ibtidaiyah Universitas Islam Negeri Maulana Malik Ibrahim Malang.

Lianasari, M.D., 2014. Hubungan Pola Asuh Orang tua dengan Konsep Diri pada Remaja Usia 12-15 Tahun di SMP Negeri 1 Sedayu Bantul Yogyakarta. Tidak diterbitkan : Stikes Jenderal Achmad Yani Yogyakarta.

Ningrum, Savia Dia., 2015. Hubungan antara Pola Asuh Otoriter Orang Tua dengan Perilaku Bullying Disekolah Pada siswa SMP. Fakultas Psikologi Mercu Buana Yogyakarta.

Notoatmodjo, S., 2010. Metode penelitian kesehatan. Jakarta: Rineka.

Nurhayati, R., 2013. Tipe Pola Asuh Orang Tua Yang Berhubungan Dengan Perilaku Bullying di SMA Islam Sudirman Ambarawa Kabupaten Semarang. Jurnal Keperawatan jiwa, Volume 1, No.1, Mei 2013; 49-59.
Rigby, K., 2010. How School Counter Bullying Policies and Procedures in Selected Australian Schools. Camberwell: Australian Council for Education Research Limited.

Santrock., 2007. Masa Perkembangan Anak. Edisi 11 Jilid 2. Jakarta: Salemba Humanika.

Schohib, M., 2010. Pola Asuh Orang Tua. Jakarta: Rineka Cipta

Septiyanah., 2019. Hubungan Antara Kecerdasan Emosi Dan Konformitas Teman Sebaya Dengan Perilaku Bullying Pada Sisa SMP Nusantara Bandar Lampung. Skripsi. Bandar Lampung : $\quad$ Fakultas Ushuluddin Dan Studi Agama Univeritas Islam Negeri Raden Intan Lampung.

Setyobudi, J., 2015. Hubungan Pola Asuh Orang Tua Dengan Perilaku Merokok Remaja Di SMP N 3 Grabag Magelang.

Sugiyono. 2011., Metode Penelitian Kuantitatif Kualitatif dan $R \& D$. Bandung : Alfabeta.

Tim Penulis Poltekes Depkes Jakarta I., 2012. Kesehatan Remaja : Problem dan Solusinya. Jakarta: Salemba.

Yayasan Semai Jiwa Amini SEJIWA., 2008. Bullying Mengatasi Kekerasan di Sekolah dan Lingkungan Sekitar Anak. Jakarta: Grasindo

Yusuf, S., 2010. Psikolog Perkembangan Anak dan Remaja. Bandung : Remaja Rosdakarya. 
Zakiyah dan Ela Zain., 2017. Faktor yang Mempengaruhi Remaja Dalam Melakukan Bullying. Jurnal Penelitian \& PPM Vol 4, No: 2, Halaman 129-389.
Tersedia

http://jurnal.unpad.ac.id/prosidin g/a rticle/viewFile/14352/6931. Diakses tanggal 1 September 2019. 